\title{
EFEKTIVITAS PEMBELAJARAN MATEMATIKA DENGAN MODEL QUANTUM TEACHING (QT) DITINJAU DARI KREATIVITAS BELAJAR SISWA KELAS VIII SMP N 2 TURI
}

\author{
Monita Dwiyani ${ }^{1)}$, Niken Wahyu Utami ${ }^{2}$ \\ Fakultas Keguruan dan Ilmu Pendidikan Universitas PGRI Yogyakarta \\ 1)e-mail: monita.dwiyani@gmail.com \\ ${ }^{2)}$ e-mail: nikenimoet@gmail.com
}

\begin{abstract}
ABSTRAK
Penelitian ini bertujuan untuk mengetahui bagaimana efektivitas model kooperatif, efektivitas model Quantum Teaching (QT), dan efektivitas model Quantum Teaching $(Q T)$ bila dibandingkan dengan model kooperatif jika ditinjau dari kreativitas belajar siswa.

Populasi dari penelitian semu ini adalah siswa kelas VIII SMP N 2 Turi yaitu VIII A, VIII B, VIII C, dan VIII D. Sampel penelitian adalah VIII B (kelas control) dan VIII A (kelas eksperimen). Instrumen penelitian berupa lembar observasi keterlaksanaan pembelajaran dan tes kreativitas yang sudah diujicobakan (untuk diketahui valid dan reliable).

Uji hipotesis berupa uji proporsi satu populasi dan uji proporsi dua populasi. Berdasarkan uji proporsi satu populasi kelas kontrol diperoleh nilai signifikansi sebesar 0,004 dengan taraf nyata $5 \%(0,004<0,05)$ sehingga dapat disimpulkan bahwa model Kooperatif tidak efektif. Sedangkan berdasarkan uji proporsi satu populasi kelas eksperimen diperoleh nilai signifikansi sebesar 0,020 dengan taraf nyata 5\% $(0,020<0,05)$ sehingga dapat disimpulkan bahwa model Quantum Teaching tidak efektif. Jika kedua model dibandingkan maka berdasarkan uji proporsi dua populasi diperoleh nilai signifikansi sebesar 0,869 dengan taraf nyata 5\% dan dapat diketahui bahwa nilai signifikansi lebih besar daripada taraf nyata $(0,869>0,05)$ sehingga dapat disimpulkan bahwa model Quantum Teaching lebih efektif daripada model Kooperatif.
\end{abstract}

Kata Kunci: $\quad$ Efektivitas Pembelajaran, Model Quantum Teaching, Kreativitas Belajar

\section{PENDAHULUAN}

Pendidikan merupakan langkah awal suatu bangsa dan negara untuk mencapai kemajuan. Tujuan pendidikan nasional tercantum dalam pasal 3 UU No. 20 Sisdiknas tahun 2003 yaitu berkembangnya potensi peserta didik agar menjadi manusia yang beriman dan bertakwa kepada Tuhan Yang Maha Esa, berakhlak mulia, sehat, berilmu, cakap, kreatif, mandiri, dan menjadi warga negara yang demokratis serta bertanggung jawab.

Salah satu pendidikan yang diberikan agar mencapai tujuan pendidikan nasional adalah pendidikan untuk mata pelajaran matematika. Menurut Sumaryanta (2009: 28), mata pelajaran matematika perlu diberikan kepada semua peserta didik mulai dari sekolah dasar juga untuk membekali peserta didik dengan kemampuan 
berpikir logis, analitis, sistematis, kritis, dan kreatif, serta kemampuan bekerjasama. Dalam mata pelajaran matematika dimuat materi-materi yang berguna bagi kehidupan baik langsung maupun tidak langsung. Salah satu peranan penting matematika dalam kehidupan adalah mengembangkan kreativitas siswa.

Berdasarkan hasil observasi di SMP N 2 Turi, proses pembelajaran yang dilaksanakan cenderung monoton dan kurang memfasilitasi siswa untuk berinteraksi dengan lingkungannya sehingga menghambat munculnya kreativitas siswa. Interaksi dalam pembelajaran matematika antara guru dengan siswa maupun antara siswa dengan siswa masih kurang. Pada saat pembelajaran, Lembar Kegiatan Siswa (LKS) yang telah diberikan hanya dikerjakan oleh beberapa siswa. Beberapa siswa yang lain cenderung bergantung kepada teman sehingga siswa yang tidak mengerjakan tidak ikut berpikir. Siswa yang tidak mengerjakan LKS justru membuat suasana kelas tidak kondusif. Baik siswa yang mengerjakan maupun tidak, cenderung terlihat bosan dan kurang antusias meskipun guru telah memberikan LKS. Kurangnya interaksi dan rendahnya daya tarik terhadap pembelajaran matematika tersebut mengakibatkan rendahnya kedekatan emosional baik antar siswa maupun antara siswa dengan guru.

Berdasarkan hasil pekerjaan siswa, hanya 8 siswa dari 30 siswa yang menjawab dengan cara berbeda dari yang diajarkan guru. Dalam mengerjakan pun siswa tidak memberikan keterangan tentang apa yang diketahui dan ditanya dari soal sehingga keluwesan siswa dalam menyelesaikan masalah matematika masih kurang.

Menurut hasil wawancara dengan ibu Titin Sumarni, S. Pd., setiap guru memberikan soal, siswa hanya meniru cara guru dan jarang melakukan inovasi dalam menyelesaikan masalah matematika. Kurangnya unsur keunikan siswa dalam menyelesaikan masalah matematika dapat diamati dari penyelesaian masalah matematika yang dilakukan siswa. Beliau juga mengatakan bahwa beberapa siswa membutuhkan waktu yang lama dalam menyelesaikan masalah matematika. Hal-hal tersebut mengindikasikan kurangnya kreativitas siswa dalam menyelesaikan masalah matematika. Menurut peneliti, kurangnya kreativitas siswa dapat diatasi dengan model pembelajaran Quantum Teaching (QT). 
Model Quantum Teaching (QT) adalah salah satu model yang efektif digunakan dalam proses pembelajaran matematika. Pernyataan tersebut mendorong peneliti untuk melakukan penelitian tentang keefektifan model Quantum Teaching (QT) dalam proses pembelajaran matematika ditinjau dari kreativitas. Untuk mengetahui keefektivan model Quantum Teaching (QT) dalam proses pembelajaran maka dibutuhkan model pembelajaran lain sebagai kontrol atau pembanding. Model pembelajaran yang digunakan sebagai kontrol atau pembanding adalah model kooperatif. Dipilihnya model kooperatif sebagai kontrol atau pembanding dikarenakan model kooperatif banyak digunakan oleh para guru dalam proses pembelajaran pada kurikulum 2013. Pada penelitian ini digunakan pembanding model kooperatif. Hamruni (2011: 118-122) mendeskripsikan bahwa model kooperatif adalah rangkaian kegiatan belajar yang dilakukan oleh siswadalam kelompokkelompok tertentu untuk mencapai tujuan pembelajaran yang telah dirumuskan.

Quantum Teaching (QT) digunakan sebagai penyelaras antara apa yang disenangi siswa dengan kreativitas siswa terhadap metematika. Dengan menggunakan model Quantum Teaching
(QT) ini diharapkan dapat lebih meningkatkan kreativitas siswa pada pembelajaran Matematika bagi siswa SMP N 2 Turi kelas VIII.

Penelitian yang relevan adalah penelitian yang dilakukan oleh Erni Ismiatun (2010) dengan judul "PENERAPAN MODEL PEMBELAJARAN QUANTUM TEACHING UNTUK MENINGKATKAN MINAT BELAJAR PAI SISWA KELAS VII D SMP N 2 PANDAK BANTUL”.

Penelitan lain yang relevan dilakukan oleh Abdullah Husin (2009) dengan judul "EFEKTIVITAS MODEL PEMBELAJARAN QUANTUM TEACHING TERHADAP HASIL BELAJAR MATEMATIKA PESERTA DIDIK POKOK BAHASAN SEGITIGA SEMESTER II KELAS VII MTs NEGERI MARGOYOSO PATI TAHUN PELAJARAN 2008/2009”. Berdasarkan kajian teori di atas, hipotesis yang diajukan dalam penelitian ini adalah:

1. Model kooperatif efektif jika ditinjau dari kreativitas belajar siswa. 
Efektivitas Pembelajaran Matematika Dengan Model Quantum Teaching (QT) Ditinjau Dari Kreativitas Belajar Siswa Kelas VIII SMP N 2 Turi

Monita Dwiyani, Niken Wahyu Utami

2. Model Quantum Teaching (QT) efektif jika ditinjau dari kreativitas belajar siswa.

3. Model Quantum Teaching (QT) lebih efektif bila dibandingkan dengan model kooperatif jika ditinjau dari kreativitas belajar siswa.

\section{METODE PENELITIAN}

Penelitian ini dilaksanakan di SMP N 2 Turi. Menurut Sugiyono (2009:117) populasi adalah wilayah generalisasi yang terdiri atas: obyek/subyek yang mempunyai kualitas dan karakteristik tertentu yang ditetapkan oleh peneliti untuk dipelajari dan kemudian ditarik kesimpulannya. Jadi populasi bukan hanya orang, tetapi juga obyek dan benda-benda alam yang lain. Populasi juga bukan sekedar jumlah yang ada pada obyek/subyek yang dipelajari, tetapi meliputi seluruh karakteristik/sifat yang dimiliki oleh subyek atau obyek itu. Populasi dari penelitian ini adalah seluruh siswa SMP N 2 Turi kelas VIII yang terdiri dari kelas VIII A, VIII, B, VIII C, dan VIII D.

Menurut Sugiyono

(2009:118) sampel adalah bagian dari jumlah dan karakteristik yang dimilki oleh populasi tersebut. Teknik yang digunakan untuk memperoleh sampel adalah simple random sampling, yaitu pemilihan kelas dengan cara mengacak atau mengundi dari 4 kelas yang ada. Dari 4 kelas yang ada dipilih dua kelas dengan cara diundi, ternyata hasil dari pengundian terpilih dua kelas. Setelah terpilih dua kelas maka dilakukan pengundian lagi dari kedua kelas yang terpilih untuk menentukan kelas kontrol dan kelas eksperimen. Hasil dari pengundian tersebut yang terpilih sebagai kelas kontrol adalah VIII B (pada kelas ini proses pembelajaran menggunakan model Kooperatif) sedangkan yang terpilih sebagai kelas eksperimen adalah VIII A (pada kelas ini proses pembelajaran menggunakan model Quantum Teaching (QT)).

Dalam penelitian eksperimen ini terdapat dua macam variabel penelitian yaitu:

1. Variabel Bebas

Dalam penelitian ini model pembelajaran terdiri dari model Quantum Teaching (QT) sebagai eksperimen dan model Kooperatif sebagai kontrol. Dalam hal ini model pembelajaran disimbolkan dengan:

a. $\quad \alpha_{1}=$ model Quantum Teaching (QT) 
b. $\quad \alpha_{2}=$ model Kooperatif

2. Variabel Terikat

Dalam penelitian ini yang bertindak sebagai variabel terikat adalah kreativitas siswa. Kreativitas adalah hasil atau taraf kemampuan yang telah dicapai siswa setelah mengikuti proses belajar mengajar dalam waktu tertentu yang diukur dan dinilai dalam suatu interval. Dalam hal ini prestasi belajar disimbolkan dengan:

a. $Y_{1}=$ kreativitas kelas eksperimen

b. $Y_{2}=$ kreativitas kelas kontrol

Penelitian tentang efektivitas pembelajaran matematika dengan model Quantum Teaching ditinjau dari Kreativitas Belajar Siswa Kelas VIII SMP N 2 Turi adalah jenis penelitian eksperimen. Akan tetapi, penelitian ini bukan merupakan penelitian eksperimen sungguhan melainkan penelitian eksperimen semu. Hal ini dikarenakan peneliti tidak mungkin melakukan kontrol atau manipulasi pada semua variabel yang relevan kecuali beberapa variabel yang diteliti.

Sugiyono (2009:66) mendeskripsikan bahwa paradigma penelitian adalah pola pikir yang menenunjukkan hubungan antara variabel yang akan diteliti yang sekaligus mencerminkan jenis dan jumlah rumusan masalah yang perlu dijawab melalui penelitian. Teori yang digunakan untuk merumuskan hipotesis, jenis dan jumlah hipotesis, dan teknik analisis statistik yang akan digunakan. Dalam penelitian ini dapat digambarkan sebagai berikut:

a. Paradigma kelas eksperimen

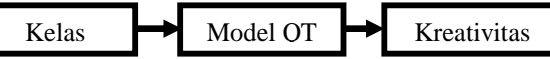

b. Paradigma kelas kontrol

Kelas $\rightarrow$ Model $\rightarrow$ Kreativitas

1. Desain Penelitian Eksperimen

Desain penelitian eksperimen yang digunakan adalah Pretest-

Posttest Control Group Design

(Sugiyono, 2009:112).

Tabel 1. Desain Penelitian Eksperimen

\begin{tabular}{|l|c|c|c||}
\hline Kelompok & Pretest & Perlakuan & Posttest \\
\hline Eksperimen & $Y_{E 1}$ & $\alpha_{1}$ & $Y_{E 2}$ \\
\hline Kontrol & $Y_{k 1}$ & $\alpha_{2}$ & $Y_{k 2}$ \\
\hline
\end{tabular}

Keterangan :

$\alpha_{1}=$ Perlakuan terhadap kelas eksperimen dengan model QT $\alpha_{2}=$ Perlakuan terhadap kelas kontrol dengan model Kooperatif $Y_{E 1}=$ Pretest kelas eksperimen $Y_{k 1}=$ Pretest kelas kontrol $Y_{E 2}=$ Posttest kelas eksperimen $Y_{k 2}=$ Posttest kelompok kontrol

Dalam penelitian ini nilai pretest digunakan untuk mengetahui apakah 
kedua kelas berasal dari populasi yang normal dan homogen serta setimbang. Sedangkan nilai posttest digunakan untuk mengetahui apakah model kooperatif dan model QT efektif digunakan dalam proses pembelajaran. Langkah-langkah dalam penelitian ini adalah:

1. Pengambilan sampel dengan cara mengundi 4 kelas yang ada untuk diambil 2 kelas.

2. Dari hasil pengambilan 2 kelas yang terpilih diundi lagi untuk menentukan mana yang dijadikan kelas kontrol dan mana yang dijadikan kelas eksperimen.

3. Menganalisis nilai pretest untuk kelas eksperimen yang diberi simbol $Y_{E 1}$ dan nilai pretest untuk kelas control $Y_{k 1}$ untuk melihat kesetimbangan kedua kelas.

4. Kelas eksperimen diberi perlakuan pembelajaran dengan model $Q T$ sedangkan kelas kontrol dengan model Kooperatif.

5. Setelah materi pembelajaran selesai, maka baik kelas eksperimen maupun kelas kontrol sama-sama diberi posttest.

6. Menganalisis nilai posttest untuk kelompok eksperimen yang diberi simbol $Y_{E 2}$ dan nilai posttest untuk kelompok kontrol $Y_{k 2}$.
Salah satu kegiatan dalam penelitian adalah menentukan cara mengukur variabel penelitian dan alat pengumpulan data. Untuk mengukur variabel diperlukan instrumen penelitian yang digunakan untuk mengumpulkan data. Adapun teknik pengumpulan data pada penelitian ini yaitu:

1. Metode Observasi digunakan untuk mengetahui keterlaksanaan model yang digunakan dalam pembelajaran matematika,

2. Metode Tes digunakan untuk mengetahui peningkatan kreativitas siswa. Metode tes merupakan teknik pengumpulan data dengan cara memberikan sejumlah pertanyaan mengenai materi yang telah diberikan kepada sampel penelitian. Pada penelitian ini model tes digunakan untuk mengumpulkan data mengenai kreativitas belajar siswa. Tes dalam penelitian ini berbentuk uraian dan berpedoman pada kurikulum 2013.

Menurut Sugiyono instrumen penelitian adalah suatu alat yang digunakan untuk mengukur variabel yang diamati. Dalam penelitian ini instrumen penelitian yang digunakan adalah lembar observasi dan tes kreativitas.

Adapun instrumen yang digunakan dalam penelitian meliputi: 
1. Lembar observasi digunakan mengetahui keterlaksanaan pembelajaran dengan QT (Quantum Teaching).

Tabel 2.Kisi-kisi Lembar Observasi Keterlaksanaan Pembelajaran Matematikadengan QT (Quantum Teaching)

\begin{tabular}{|c|l|c|}
\hline No. & \multicolumn{1}{|c|}{ Indikator } & $\begin{array}{c}\text { No. } \\
\text { Butir }\end{array}$ \\
\hline & $\begin{array}{l}\text { Kegiatan } \\
\text { pendahuluan }\end{array}$ & $1,2,3$ \\
\hline 1. & Guru memotivasi & 4,5 \\
\hline 2. & Kegiatan inti & $\begin{array}{l}\text { Tumbuhkan. } \\
\text { Menumbuhkan rasa } \\
\text { ingin tahu siswa. }\end{array}$ \\
\hline 3. & $\begin{array}{l}\text { Alami. Membimbing } \\
\text { siswa mengamati } \\
\text { lingkungan sekitar }\end{array}$ & 6 \\
\hline 4. & $\begin{array}{l}\text { Namai. Memberikan } \\
\text { kata kunci, konsep, } \\
\text { model, rumus atau } \\
\text { strategi atas } \\
\text { pengalaman yang telah } \\
\text { diperoleh siswa. }\end{array}$ & 7,8 \\
\hline 5. & $\begin{array}{l}\text { Demonstrasikan. } \\
\text { Mempersentasikan hasil } \\
\text { diskusi masing-masing } \\
\text { kelompok }\end{array}$ & 9,10 \\
\hline 6. & $\begin{array}{l}\text { Rayakan. } \\
\text { memberikan puru } \\
\text { kepada siswa. }\end{array}$ & 11 \\
\hline 7. & Penutup & 12,13 \\
\hline & Membuat kesimpulan \\
\hline
\end{tabular}

Tabel 3.Kisi-kisi Lembar Observasi Keterlaksanaan Pembelajaran Matematika dengan Kooperatif

\begin{tabular}{|c|l|c|}
\hline No. & \multicolumn{1}{|c|}{ Indikator } & No. Butir \\
\hline & $\begin{array}{l}\text { Kegiatan } \\
\text { pendahuluan }\end{array}$ & \\
\hline 1. & Guru memotivasi & $1,2,3,4,5$ \\
\hline & Kegiatan inti & \\
\hline 2. & Mengamati & 6 \\
\hline 3. & Menanya & 7 \\
\hline 4. & Mengeksplorasi & 8 \\
\hline 5. & Mengasosiasi & 9,10 \\
\hline 6. & Mengkomunikasikan & 11,12 \\
\hline & Penutup & \\
\hline 7. & Membuat kesimpulan & $13,14,15$ \\
\hline
\end{tabular}

2. Tes Kreativitas untuk mengetahui peningkatan kreativitas siswa.

Tabel 4.Kisi-kisi soal tes kreativitas

\begin{tabular}{|l|l|c|c|c|}
\hline No & Indikator & $\begin{array}{c}\text { Aspek } \\
\text { kreativitas }\end{array}$ & $\begin{array}{c}\text { Nomor } \\
\text { Soal }\end{array}$ & $\begin{array}{c}\text { Bentuk } \\
\text { Soal }\end{array}$ \\
\hline 1 & $\begin{array}{l}\text { Menentukan } \\
\text { volume kubus }\end{array}$ & $\begin{array}{l}\text { Kelancaran } \\
\text { Keluwesan } \\
\text { Keunikan }\end{array}$ & 1 & Uraian \\
\hline 2 & $\begin{array}{l}\text { Menghitung } \\
\text { luas } \\
\text { permukaan } \\
\text { kubus }\end{array}$ & $\begin{array}{l}\text { Kelancaran } \\
\text { Keluwesan } \\
\text { Keunikan }\end{array}$ & 2 & Uraian \\
\hline 3 & $\begin{array}{l}\text { Menghitung } \\
\text { jumlah } \\
\text { seluruh } \\
\text { panjang rusuk } \\
\text { kubus }\end{array}$ & $\begin{array}{l}\text { Kelancaran } \\
\text { Keluwesan } \\
\text { Keunikan }\end{array}$ & 3 & Uraian \\
\hline
\end{tabular}

Untuk mengukur kreativitas siswa dalam pembelajaran matematika adalah dengan tes kreativitas. Adapun pedoman penskoran didasarkan pada indikator tes kreativitas matematika.

Analisis data penelitian merupakan langkah yang sangat penting dalam kegiatan penelitian, penggunaan teknik analisis data yang benar dan tepat akan menghasilkan kesimpulan yang benar. Analisis data yang digunakan untuk mengetahui apakah kemampuan awal kedua sampel/kelas sama atau tidak adalah uji kesetimbangan kemampuan awal yang menggunakan statistik uji $t$, dengan langkah-langkah sebagai berikut:

a. Hipotesis

$H_{0}: \mu_{1}=\mu_{2}$

(kelas kontrol dan kelas eksperimen kemampuannya sama)

$H_{1}: \mu_{1} \neq \mu_{2}$

(kelas kontrol dan kelas eksperimen kemampuannya tidak sama) 
b. Tingkat Signifikasi: $\alpha=5 \%$

c. Statistik Uji

$$
\begin{aligned}
t_{o b s} & =\frac{\left(\overline{x_{1}}-\overline{x_{2}}\right)}{s_{p} \sqrt{\frac{1}{n_{1}}+\frac{1}{n_{2}}}} \\
s_{p}{ }^{2} & =\frac{\left(n_{1}-1\right) s_{1}{ }^{2}-\left(n_{2}-1\right) s_{2}{ }^{2}}{n_{1}+n_{2}-2}
\end{aligned}
$$

Dengan:

$t=$ harga statistik uji

$x_{1} \quad=$ rata-rata pretest kelas

eksperimen

$x_{2}=$ rata-rata pretest kelas kontrol

$n_{1}=$ jumlah anggota kelas

eksperimen

$n_{2}=$ jumlah anggota kelas kontrol

$s_{1}^{2}=$ variansi kelas eksperimen

$s_{2}^{2}=$ variansi kelas kontrol

$S_{p}=$ variansi gabungan

d. Keputusan Uji: $H_{0}$ ditolak jika $t_{\text {obs }}<-t_{(0,025)\left(d_{k}\right)} \quad$ atau $t_{o b s}>t_{(0,025)\left(d_{k}\right)}$

Sebelum melakukan uji kesetimbangan terlebih dahulu diperlukan uji prasyarat apakah kedua kelas tersebut normal dan homogen. Jika kedua kelas memiliki kemampuan awal yang sama maka dalam melakukan uji hipotesis hanya menggunakan hasil posttest dari masing-masing kelas. Tetapi, jika kedua kelas memiliki kemampuan yang berbeda maka dalam melakukan uji hipotesis menggunakan hasil pretest dan posttest dari masingmasing kelas. Dengan cara mencari gain (selisih rataan) antara hasil pretest dan postest dari masing-masing kelas.

Sebelum melakukan uji kesetimbangan ini maka harus dilakukan dahulu uji asumsi terhadap sampel penelitian. Dalam hal ini uji asumsi yang digunakan adalah:

1. Uji Normalitas Populasi

Uji ini digunakan untuk mengetahui apakah sampel penelitian ini berasal dari populasi yang berdistribusi normal atau tidak. Uji normalitas pada penelitian ini menggunakan model Liliefors dengan prosedur sebagai berikut:

a. Hipotesis

$H_{0}$ : sampel berasal dari populasi yang berdistribusi normal

$H_{1}$ : sampel tidak berasal dari populasi yang berdistribusi normal

b. Tingkat Signifikasi: $\alpha=5 \%$

c. Statistik Uji

$$
\begin{aligned}
& L_{o b s}=\operatorname{maks}\left|F\left(z_{i}\right)-S\left(z_{i}\right)\right| \\
& z_{i}=\frac{x_{i}-\bar{x}}{s}
\end{aligned}
$$


Dengan:

$L_{o b s}=$ koefisien Liliefors dari

pengamatan

$z_{i} \quad=$ skor standar

$F\left(z_{i}\right) \quad=P\left(Z \leq z_{i}\right)$ dengan $Z$

$\sim N(0,1)$

$S\left(z_{i}\right) \quad=$ kesetimbangan cacah

$z \leq z_{i}$ terhadap seluruh $z_{i}$

$s=$ standar deviasi

d. Keputusan Uji: $H_{0}$ ditolak jika

$$
L_{o b s}>L_{(0,05)(n)}
$$

Jika kedua kelas berasal dari distribusi normal maka dalam melakukan uji hipotesis dapat menggunakan statistik uji yang mensyaratkan sampel berasal dari distribusi normal. Tetapi, jika kedua kelas berasal dari populasi yang tidak berdistribusi normal maka dalam melakukan uji hipotesis tidak dapat menggunakan statistik uji yang mensyaratkan sampel berasal dari distribusi normal.

2. Uji Homogenitas Variansi Populasi

Uji ini digunakan untuk mengetahui apakah kedua kelas (kelas eksperimen dan kelas kontrol) memiliki variansi yang sama atau tidak. Statistik uji yang digunakan dalam uji homogenitas variansi populasi adalah uji Bartlett dengan langkah-langkah sebagai berikut:

a. Hipotesis

$H_{0}: \sigma_{1}^{2} \neq \sigma_{2}^{2}$ (kedua kelas memiliki variansi yang tidak homogen)

$$
\begin{aligned}
& H_{1}: \sigma_{1}^{2}=\sigma_{2}{ }^{2} \text { (kedua kelas } \\
& \text { memiliki variansi yang } \\
& \text { homogen) }
\end{aligned}
$$

b. Tingkat Signifikasi:

$\alpha=5 \%$

c. Statistik Uji

$$
\chi^{2}{ }_{o b s}=(\ln 10)\left\{B-\sum\left(n_{i}-1\right)\right.
$$

dimana:

$$
s_{p}{ }^{2}=\left(\sum \left(n_{i}-1 B=\left(\log s_{p}{ }^{2}\right.\right.\right.
$$

Dengan:

$$
\begin{aligned}
& \chi^{2}{ }^{2}{ }^{b}=\text { harga statistik uji } \\
& B \text { = harga satuan } \mathrm{B} \\
& n_{i}=\text { jumlah anggota kelas } \\
& \text { dimana } i=1,2(1=\text { kelas } \\
& \text { eksperimen dan } 2=\text { kelas } \\
& \text { kontrol) } \\
& s_{i}=\text { variansi kelas } \\
& \text { dimana } i=1,2(1=\text { kelas } \\
& \text { eksperimen dan } 2=\text { kelas } \\
& \text { kontrol) } \\
& S_{p}=\text { variansi gabungan }
\end{aligned}
$$


d. Keputusan Uji: $H_{0}$ ditolak

$$
\text { jika } \chi^{2}{ }_{\text {obs }} \geq \chi^{2}{ }^{2}(0,95)(k-1)
$$

(Purwanto, 2011:180-182)

Setelah uji asumsi dilakukan maka Stindakan selanjutnya adalah menguji hipotesis. Hipotesis yang diuji adalah:

\section{Efektivitas Model Kooperatif}

Suatu model pembelajaran dikatakan efektif jika lebih dari $70 \%$ siswa telah mencapai nilai KKM (70). Statistik uji yang digunakan adalah uji- $t$ satu populasi. Langkah-langkah dalam pengujian ini adalah sebagai berikut:

a. Hipotesis

$$
H_{0}: \pi \geq 0,7 \text { (Model }
$$

Kooperatif efektif)

$$
H_{1}: \pi<0,7 \quad \text { (Model }
$$

Kooperatif tidak efektif)

b. Tingkat Signifikasi: $\alpha=5 \%$

c. Statistik Uji

$$
t_{o b s}=\frac{x_{k} / n_{k}-0,7}{\sqrt{(0,7)(0,3) / n_{k}}}
$$

Dengan:

$z_{\text {obs }}=$ harga statistik uji

$x_{k}=$ jumlah siswakelas

kontrol yang mencapai nilai

\section{KKM}

$$
n_{k}=\text { besar sampel kelas }
$$

kontrol

d. KeputusanUji: $H_{0}$ ditolak jika

$$
z_{o b s}<-z_{(0,05)}
$$

\section{Efektivitas Model QT}

Pengujian ini dilakukan untuk mengetahui apakah model QT efektif digunakan dalam proses pembelajaran matematika terutama pada materi luasan segi empat. Suatu model pembelajaran dikatakan efektif jika lebih dari $70 \%$ siswa telah mencapai nilai KKM (70). Statistik uji yang digunakan adalah uji- $t$ satu populasi. Langkah-langkah dalam pengujian ini adalah sebagai berikut:

a. Hipotesis

$$
H_{0}: \pi \geq 0,7
$$

(Model

QT efektif)

$$
H_{1}: \pi<0,7 \quad \text { (Model }
$$

QT tidak efektif)

b. Tingkat Signifikasi: $\alpha=5 \%$

c. Statistik Uji

$$
z_{\text {obs }}=\frac{x_{e} / n_{e}-0,7}{\sqrt{(0,7)(0,3) / n_{e}}}
$$

Dengan:

$$
z_{o b s}=\text { harga statistik uji }
$$


$x_{e}=$ jumlah siswa kelas

eksperimen yang mencapai nilai

KKM

$n_{e}=$ besar sampel kelas

eksperimen

d. KeputusanUji: $H_{0}$ ditolak jika $z_{o b s}<-z_{(0,05)}$

(Tomo Djudin, 2013:13)

3. Model QT lebih efektif daripada model Kooperatif

Pengujian ini dilakukan untuk mengetahui apakah Model QT lebih efektif daripada model Kooperatif digunakan dalam proses pembelajaran matematika terutama. Statistik uji yang digunakan adalah uji kesetimbangan dua populasi yang mencapai nilai KKM yaitu 70 . Langkah-langkah dalam pengujian ini adalah:

a. Hipotesis

$H_{0}: \pi_{1}>\pi_{2}$

(Model QT lebih efektif dari model Kooperatif)

$H_{1}: \pi_{1} \leq \pi_{2}$

(Model QT tidak lebih efektif daripada model Kooperatif)

Dengan $\pi_{1}$ sebagai hasil perlakuan dengan model QT dan $\pi_{2}$ sebagai hasil perlakuan dengan model kooperatif.

b. Tingkat Signifikan: $\alpha=5 \%$ c. Statistik Uji

$$
z_{o b s}=\frac{x_{e} / n_{e}-x_{k} / n_{k}}{\sqrt{p q\left\{\left(1 / n_{e}\right)+\left(1 / n_{k}\right)\right\}}}
$$

$p=\frac{x_{e}+x_{k}}{n_{e}+n_{k}}$ dan $q=1-p$

Dengan:

$z_{o b s} \quad=$ harga statistik uji

$x_{e}=$ jumlah siswa kelas eksperimen yang mencapai nilai KKM

$x_{k}=$ jumlah siswa kelas kontrol yang mencapai nilai KKM

$n_{e}=$ besar sampel kelas eksperimen

$$
\begin{aligned}
n_{k} & ={ }_{\text {besar }} \text { sampel kelas kontrol } \\
p & =\text { kesetimbangan tertimbang }
\end{aligned}
$$

d. Keputusan Uji: $H_{0}$ ditolak jika

$$
z_{\text {obs }}>z_{(0,05)}
$$

\section{HASIL PENELITIAN DAN PEMBAHASAN}

\section{Pengujian Validitas Instrumen}

Sebelum soal pretest dan posttest yang disusun oleh peneliti digunakan sebagai instrumen dalam penelitian maka soal pretest dan posttest ini divalidasikan kepada validator untuk divalidasi dari segi isi. Selain itu soal pretest dan posttest ini diujicobakan 
Efektivitas Pembelajaran Matematika Dengan Model Quantum Teaching (QT) Ditinjau Dari Kreativitas Belajar Siswa Kelas VIII SMP N 2 Turi

Monita Dwiyani, Niken Wahyu Utami

terlebih dahulu. Ujicoba ini dilakukan untuk mengetahui validitas konstruk dari masing-masing butir soal.Subjek yang dijadikan untuk ujicoba soal tes adalah siswa kelas VIII C SMPN 2 Turi. Nilai koefisien dari masing-masing butir soal disajikan pada tabel berikut.

\section{Tabel 5.Hasil Validitas Instrumen Pretest}

\begin{tabular}{|c|c|c|c|c|c|}
\hline & & Nilai 1 & Nilai 2 & Nilai 3 & skor total \\
\hline \multirow[t]{3}{*}{ Nilai 1} & Pearson Correlation & 1 & $.775^{\prime \prime}$ & $.617^{\prime \prime}$ & $.942^{\prime \prime}$ \\
\hline & Sig. (2-tailed) & & .000 & .000 & .000 \\
\hline & $\mathrm{N}$ & 32 & 32 & 32 & 32 \\
\hline \multirow[t]{3}{*}{ Nilai 2} & Pearson Correlation & $.775^{\prime \prime}$ & 1 & $.626^{\prime \prime}$ & $.883^{\prime \prime}$ \\
\hline & Sig. (2-tailed) & .000 & & .000 & .000 \\
\hline & $\mathrm{N}$ & 32 & 32 & 32 & 32 \\
\hline \multirow[t]{3}{*}{ Nilai 3} & Pearson Correlation & $.617^{\prime \prime}$ & $.626 "$ & 1 & $.813^{\prime \prime}$ \\
\hline & Sig. (2-tailed) & .000 & .000 & & .000 \\
\hline & $\mathrm{N}$ & 32 & 32 & 32 & 32 \\
\hline \multirow[t]{3}{*}{ skor total } & Pearson Correlation & $.942^{\prime \prime}$ & $.883^{\prime \prime}$ & $.813^{\prime \prime}$ & 1 \\
\hline & Sig. (2-tailed) & .000 & .000 & .000 & \\
\hline & N & 32 & 32 & 32 & 32 \\
\hline
\end{tabular}

\begin{tabular}{|r|r|}
\hline $\begin{array}{c}\text { Cronbach's } \\
\text { Alpha }\end{array}$ & N of Items \\
\hline .805 & 3 \\
\hline
\end{tabular}

Tabel 6.Hasil Validitas Instrumen Posttest

\begin{tabular}{|c|c|c|c|c|c|}
\hline & & Nilai 1 & Nilai 2 & Nilai 3 & skor total \\
\hline \multirow[t]{3}{*}{ Nilai 1} & Pearson Correlation & 1 & $.612^{\prime \prime}$ & $.430^{\prime}$ & $.864 "$ \\
\hline & Sig. (2-tailed) & & .000 & .014 & .000 \\
\hline & $\mathrm{N}$ & 32 & 32 & 32 & 32 \\
\hline \multirow[t]{3}{*}{ Nilai 2} & Pearson Correlation & $.612^{\prime \prime}$ & 1 & $.583^{\prime \prime}$ & $.861^{\prime \prime}$ \\
\hline & Sig. (2-tailed) & .000 & & .000 & .000 \\
\hline & N & 32 & 32 & 32 & 32 \\
\hline \multirow[t]{3}{*}{ Nilai 3} & \multirow{2}{*}{$\begin{array}{l}\text { Pearson Correlation } \\
\text { Sig. (2-tailed) }\end{array}$} & $.430^{\circ}$ & $.583 "$ & 1 & $.764 "$ \\
\hline & & .014 & .000 & & .000 \\
\hline & $\mathrm{N}$ & 32 & 32 & 32 & 32 \\
\hline \multirow[t]{3}{*}{ skor total } & Pearson Correlation & $.864^{\prime \prime}$ & $.861 "$ & $.764^{\prime \prime}$ & 1 \\
\hline & Sig. (2-tailed) & .000 & .000 & .000 & \\
\hline & $\mathrm{N}$ & 32 & 32 & 32 & 32 \\
\hline \multicolumn{6}{|c|}{ \#. Correlation is significant at the 0.01 level (2-tailed). } \\
\hline \multicolumn{6}{|c|}{${ }^{*}$. Correlation is significant at the 0.05 level (2-tailed). } \\
\hline & \multicolumn{2}{|c|}{$\begin{array}{c}\text { Cronbach's } \\
\text { Alpha }\end{array}$} & \multicolumn{2}{|c|}{ N of Items } & \\
\hline & \multicolumn{2}{|r|}{.760} & & 3 & \\
\hline
\end{tabular}

Dari perhitungan analisis hasil ujicoba dengan menggunakan rumus korelasi dari Karl Pearson diketahui bahwa nilai koefisien korelasi dari setiap butir soal lebih dari 0,3 sehingga ketiga soal dari masing-masing pretest dan posttest dinyatakan valid. Karena instrumen dinyatakan valid dan reliabel maka instrumen ini dapat digunakan dalam penelitian ini.

\section{Deskriptif Data Pretest}

Sebelum perlakuan diberikan kepada masing-masing kelas maka kedua kelas (kelas kontrol dan kelas eksperimen) diberi tes awal (pretest). Hasil dari nilai pretest ini digunakan peneliti untuk menentukan langkah selanjutnya. Data statistik nilai pretest dari masing-masing kelas disajikan dalam Tabel 9 berikut.

Tabel 7.Data Deskriptif Nilai Pretest Kelas Eksperimen dan Kelas Kontrol

\begin{tabular}{|l|r|r|r|c|r|c|}
\hline & \multicolumn{1}{|c|}{$\mathrm{N}$} & Minimum & Maximum & Mean & Std. Deviation & Variance \\
\hline Nilia pretes eksperimen & 32 & 11.11 & 66.67 & 39.1196 & 13.76061 & 189.354 \\
Nilai pretes kontrol & 32 & 18.51 & 62.96 & 36.8037 & 11.63678 & 135.415 \\
Valid N (listwise) & 32 & & & & & \\
\hline
\end{tabular}

Jika dilihat dari data yang ada pada tabel dimana:

1. Nilai rata-rata kelas eksperimen yaitu 39,11 lebih tinggi daripada nilai rata-rata kelas kontrol yaitu 36,80 ;

2. Nilai tertinggi kelas eksperimen yaitu 66,67 lebih tinggi dari nilai tertinggi kelas kontrol yaitu 62,96;

3. Nilai terendah kelas eksperimen yaitu 11,11 lebih rendah dari nilai terendah kelas kontrol yaitu 18,51. 
Maka dapat disimpulkan bahwa kemampuan awal kelas eksperimen lebih baik daripada kelas kontrol. Tetapi data-data yang ada pada tabel tidak bisa dijadikan dasar untuk menentukan apakah kemampuan awal kelas eksperimen lebih tinggi daripada kelas kontrol. Karena untuk mengetahui bagaimana kemampuan awal dari masing-masing kelas yang sebenarnya harus menggunakan perhitungan secara statistik. Statistik uji yang digunakan untuk mengetahui bagaimana kemampuan awal dari masing-masing kelas adalah uji $t$. Data proses perhitungan ini dapat dilihat pada Lampiran 4. Secara umum hasil perhitungan dijabarkan sebagai berikut:

a. Hipotesis

$H_{0}: \mu_{1}=\mu_{2}$

(kelas kontrol dan kelas eksperimen kemampuannya sama)

$H_{1}: \mu_{1} \neq \mu_{2}$

(kelas kontrol dan kelas eksperimen kemampuannya tidak sama)

b. Tingkat Signifikasi: $\alpha=5 \%$

c. Statistik Uji dengan SPSS 16.0

Tabel 8.Hasil Tes Kemampuan Awal Paired Sample Test

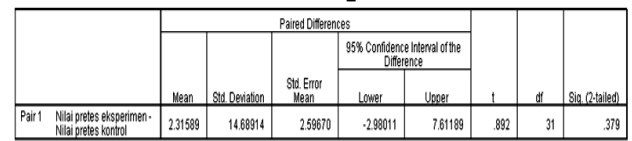

d. Keputusan Uji: $H_{0}$ ditolak jika $t_{o b s}<-t_{(0,025)\left(d_{k}\right)}$ atau $t_{o b s}>t_{(0,025)\left(d_{k}\right)}$

Dari hasil tersebut dapat dilihat bahwa nilai signifikansisi sebesar 0,379 $(0,379>0,05) \quad$ maka $\quad H_{0}$ diterima artinya bahwa kemampuan awal (pretest) kedua kelas tersebut sama. Dari hasil perhitungan tersebut ternyata $t_{o b s}=0,892$ sehingga $H_{0}$ diterima.Jadi, dapat disimpulkan bahwa kedua kelas memiliki kemampuan awal yang sama.

\section{Deskriptif Data Posttest}

Setelah perlakuan (Model Kooperatif dan Model Quantum Teaching) diberikan kepada masingmasing kelas maka kedua kelas (kelas kontrol dan kelas eksperimen) diberi tes akhir (posttest). Hasil dari nilai posttest ini digunakan untuk mengetahui keefektifan dari masing-masing model pembelajaran yang telah digunakan pada kedua kelas. Data statistik nilai posttest dari masing-masing kelas disajikan dalam tabel berikut.

\section{Tabel 9.Data Statistik Deskriptif Nilai Posttest Kelas Eksperimen dan Kelas Kontrol}

\begin{tabular}{|l|r|r|r|r|r|r|}
\hline & \multicolumn{1}{|c|}{$\mathrm{N}$} & Minimum & Maximum & Mean & Std. Deviation & Variance \\
\hline Nilai postes eksperimen & 32 & 48.15 & 77.77 & 66.6656 & 7.69803 & 59.260 \\
Nilai postes kontrol & 32 & 48.15 & 77.77 & 66.3188 & 6.60751 & 43.659 \\
Valid N (listwise) & 32 & & & & & \\
\hline
\end{tabular}

Jika dilihat dari data yang ada pada tabel dimana: 
1. Nilai rata-rata kelas kontrol yaitu 66,31 lebih rendah dari nilai KKM (70);

2. Nilai rata-rata kelas eksperimen yaitu 66,67 lebih rendah dari nilai KKM (70);

3. Nilai rata-rata kelas eksperimen yaitu 66,67 lebih tinggi daripada nilai rata-rata kelas kontrol yaitu 66,31 .

Maka dapat disimpulkan bahwa model Kooperatif dan model Quantum Teaching tidak efektif serta model Quantum Teaching lebih efektif daripada model Kooperatif. Tetapi datadata yang ada pada tabel tidak bisa dijadikan dasar untuk menentukan apakah model Kooperatif dan model Quantum Teaching efektif serta model Quantum Teaching lebih efektif daripada model Kooperatif. Karena untuk mengetahui keefektifan dari model Kooperatif dan model Quantum Teaching harus menggunakan perhitungan secara statistik yaitu dengan uji proporsi satu populasi. Sedangkan unuk mengetahui apakah model Quantum Teaching lebih efektif daripada model Kooperatif harus menggunakan perhitungan secara statistik yaitu dengan uji proporsi dua populasi.

\section{Analisis Uji Hipotesis}

Sebelum melakukan uji hipotesis dengan menggunakan uji proporsi satu populasi dan uji proporsi dua populasi maka harus dilakukan uji asumsi terhadap hasil pretest dari masingmasing kelas. Uji asumsi yang digunakan dalam penelitian ini adalah:

a. Uji Normalitas Populasi Kelas Kontrol dan Eksperimen

Pada uji normalitas ini statistik uji yang digunakan adalah model Liliefors. Secara umum hasil perhitungan dijabarkan sebagai berikut:

1. Hipotesis

$H_{0}$ : sampel berasal dari populasi yang berdistribusi normal

$H_{1}$ : sampel tidak berasal dari populasi yang berdistribusi normal

2. Tingkat Signifikasi: $\alpha=5 \%$

3. StatistikUji dengan SPSS 16.0

$$
L_{o b s}=\operatorname{maks}\left|F\left(z_{i}\right)-S\left(z_{i}\right)\right|
$$

4. KeputusanUji: $H_{0}$ ditolak jika $L_{o b s}>L_{(0,05)(n)}$ 
Tabel 10.Hasil Normalitas Data Posttest

\begin{tabular}{|l|r|r|r|r|r|r|}
\hline & \multicolumn{3}{|c|}{ Kolmogorov-Smimover| } & \multicolumn{3}{c|}{ Shapiro-Wilk } \\
\cline { 2 - 7 } & Statistic & \multicolumn{1}{|c|}{ df } & \multicolumn{1}{|c|}{ Siq. } & Statistic & \multicolumn{1}{c|}{ df } & \multicolumn{1}{c|}{ Siq. } \\
\hline Nilai postes eksperimen & .128 & 32 & $.200^{\circ}$ & .936 & 32 & .059 \\
Nilai postes kontrol & .149 & 32 & .067 & .953 & 32 & .181 \\
\hline
\end{tabular}
a. Lilliefors Significance Correction
*. This is a lower bound of the true significance.

Dari hasil tersebut dapat dilihat pada kolom KolmogorovSmirnova dan Shapiro-Wilk bahwa nilai signifikansi untuk nilai Posttest kelompok Eksperimen adalah 0,200 dan 0,059 . Nilai tersebut lebih besar dari $\alpha=0,05$ artinya sebaran pada kelompok eksperimen bernilai normal. Pada kelompok kontrol, dilihat dari kolom Kolmogorov-Smirnova dan Shapiro-Wilk bahwa nilai signifikansi untuk nilai Posttest adalah 0,067 dan 0,181. Kedua nilai tersebut lebih besar dari $\alpha=0,05$ artinya sebaran pada kelompok kontrol bernilai normal. Jadi, dapat disimpulkan bahwa kedua kelas berdistribusi normal.

b. Uji Homogenitas Variansi Populasi Pada uji homogenitas variansi populasi ini statistik uji yang digunakan adalah uji Bartlett. Secara umum hasil perhitungan dijabarkan sebagi berikut:

1. Hipotesis
$H_{0}: \sigma_{1}^{2}=\sigma_{2}^{2} \quad$ (kedua kelas memiliki variansi yang homogen) $H_{1}: \sigma_{1}^{2} \neq \sigma_{2}^{2} \quad$ (kedua kelas memiliki variansi yang tidak homogen)

2. Tingkat Signifikasi: $\alpha=5 \%$

3. Statistik Uji dengan SPSS 16.0 $\chi^{2}{ }_{o b s}=(\ln 10)\left\{B-\sum\left(n_{i}-1\right) \log s_{i}^{2}\right\}$

4. Keputusan Uji: ${ }^{H_{0}}$ ditolak jika $\chi_{o b s}^{2} \geq \chi_{(0,95)(k-1)}^{2}$

Tabel 11. Hasil Tes Homogenitas Data Posttest

\begin{tabular}{|r|r|r|r|}
\hline $\begin{array}{c}\text { Nilai } \\
\text { Levene } \\
\text { Statistic }\end{array}$ & \multicolumn{1}{c|}{$\mathrm{df1}$} & \multicolumn{1}{c|}{$\mathrm{df2}$} & \multicolumn{1}{c|}{ Siq. } \\
\hline .421 & 1 & 62 & .519 \\
\hline
\end{tabular}

Dari hasil tersebut maka dapat dilihat bahwa nilai signifikansi sebesar 0,519. Nilai tersebut lebih besar dari $\alpha=0,05$ artinya kedua kelompok berasal dari populasi yang homogen. Jadi, dapat disimpulkan bahwa kedua kelas homogen.

Setelah uji asumsi terpenuhi maka dilakukan pengujian hipotesis. Hipotesis-hipotesis yang diuji dalam penelitian ini adalah:

1. Model pembelajaran Kooperatif tidak efektif jika digunakan pada proses pembelajaran matematika ditinjau dari kreativitas belajar siswa. Dalam 
Efektivitas Pembelajaran Matematika Dengan Model Quantum Teaching (QT) Ditinjau Dari Kreativitas Belajar Siswa Kelas VIII SMP N 2 Turi

Monita Dwiyani, Niken Wahyu Utami

hal ini hasil nilai posttest dari kelas kontrol dihitung secara statistik dengan menggunakan uji proporsi satu populasi. Secara umum hasil perhitungan dijabarkan sebagai berikut:

a. Hipotesis

$$
H_{0}: \pi \geq 0,7
$$

(Model Kooperatif efektif)

$$
H_{1}: \pi<0,7
$$

(Model Kooperatif tidak efektif)

b. Tingkat Signifikasi: $\alpha=5 \%$

c. Statistik Uji

$$
z_{\text {obs }}=\frac{x_{k} / n_{k}-0,7}{\sqrt{(0,7)(0,3) / n_{k}}}
$$

Tabel 12.Hasil Uji Efektivitas Model Kooperatif One-Sample Test

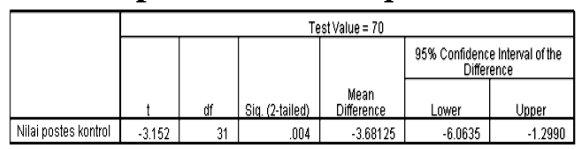

d. Keputusan Uji: $H_{0}$ ditolak jika

$$
\text { d. }{ }^{o b s}<-z_{(0,05)}
$$

Dari proses perhitungan, ternyata hasil signifikansi sebesar 0,004. Dari hasil perhitungan tersebut ternyata $\alpha=0,05>0,004 \quad$ sehingga $H_{0}$ ditolak. Jadi, dapat disimpulkan bahwa model Kooperatif tidak efektif.
2. Model pembelajaran Quantum Teaching tidak efektif jika digunakan pada proses pembelajaran matematika ditinjau dari kreativitas belajar siswa. Dalam hal ini hasil nilai posttest dari kelas eksperimen dihitung secara statistik dengan menggunakan uji proporsi satu populasi. Secara umum hasil perhitungan dijabarkan sebagai berikut:

a. Hipotesis

$$
H_{0}: \pi \geq 0,7 \text { (Model Quantum }
$$

Teaching efektif)

$$
H_{1}: \pi<0,7
$$

(Model

Quantum Teaching tidak efektif)

b. Tingkat Signifikasi: $\alpha=5 \%$

c. Statistik Uji dengan SPSS 16.0

$$
z_{o b s}=\frac{x_{e} / n_{e}-0,7}{\sqrt{(0,7)(0,3) / n_{e}}}
$$

Tabel 13. Hasil Uji Efektivitas Quantum Teaching One-Sample Test

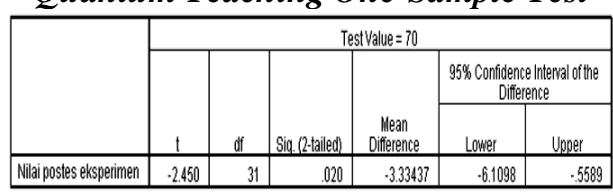

d. Keputusan Uji: $H_{0}$ ditolak jika

d. $z_{o b s}<-z_{(0,05)}$

Dari proses perhitungan, ternyata hasil signifikansi sebesar 0,020. Dari hasil 
perhitungan tersebut ternyata

$\alpha=0,05>0,020 \quad$ sehingga

$H_{0}$ ditolak. Jadi, dapat

disimpulkan bahwa model

Quantum Teaching tidak efektif.

3. Proses pembelajaran yang menggunakan model Quantum Teaching lebih efektif dibandingkan dengan proses pembelajaran yang menggunakan model Kooperatif ditinjau dari kreativitas belajar siswa. Dalam hal ini hasil nilai posttest dari kelas kontrol dan kelas eksperimen dihitung secara statistik dengan menggunakan uji proporsi dua populasi. Secara umum hasil perhitungan dijabarkan sebagai berikut:

a. Hipotesis

$$
H_{0}: \pi_{e}>\pi_{k} \text { (Model Quantum }
$$

Teaching lebih efektif daripada model Kooperatif)

$$
H_{1}: \pi_{e} \leq \pi_{k} \text { (Model Quantum }
$$

Teaching tidak lebih efektif dari Model Kooperatif)

b. Tingkat Signifikasi: $\alpha=5 \%$

c. Statistik Uji dengan SPSS 16.0

$$
z_{\text {obs }}=\frac{x_{e} / n_{e}-x_{k} / n_{k}}{\sqrt{p q\left\{\left(1 / n_{e}\right)+\left(1 / n_{k}\right)\right\}}}
$$

Hipotesis Paired Samples

Test

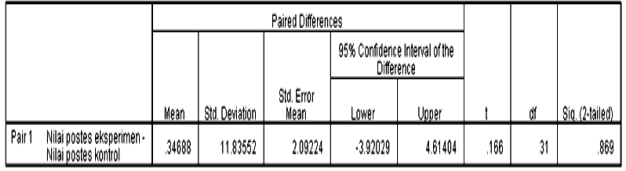

d. Keputusan Uji: $H_{0}$ ditolak jika

d. $:$ obs $>z_{(0,05)}$

Dari proses perhitungan, ternyata hasil signifikansi sebesar 0,869. Dari hasil perhitungan tersebut ternyata $\alpha=0,05<0.869 \quad$ sehingga $H_{0}$ diterima. Jadi, dapat disimpulkan bahwa model Quantum Teaching lebih efektif daripada model Kooperatif.

Dari hasil penelitian yang dilakukan oleh peneliti ternyata model Quantum Teaching lebih efektif daripada model Kooperatif. Hal ini dapat dilihat dari perhitungan secara statistik dengan menggunakan uji proporsi dua populasi. Dimana dari hasil perhitungan tersebut nilai signifikansi sebesar 0,869 sehingga $H_{0}$ (model Quantum Teaching lebih efektif daripada model Kooperatif) diterima. Hasil penelitian ini sesuai denganpenelitian yang dilakukan oleh Erni Ismiatun (2010) dengan judul 
Efektivitas Pembelajaran Matematika Dengan Model Quantum Teaching (QT) Ditinjau Dari Kreativitas Belajar Siswa Kelas VIII SMP N 2 Turi

Monita Dwiyani, Niken Wahyu Utami

TEACHING

UNTUK

MENINGKATKAN MINAT BELAJAR

PAI SISWAKELAS VII D SMP N 2

PANDAK BANTUL". Hasil penelitian

menunjukkan: Penerapan model

pembelajaran Quantum Teaching dapat

meningkatkan minat belajar PAI siswa

kelas VII D SMP N 2 Pandak Bantul.

Minat belajar siswa mengalami

peningkatan dari siklus I, siklus II dan

siklus III. Dengan diterapkannya model pembelajaran Quantum Teaching minat siswa meningkat dan termasuk dalam kategori baik. Hal ini juga ditunjukkan dengan adanya peningkatan tiap aspek, aspek adanya perhatian dan antusiasme siswa dalam mengikuti pembelajaran mengalami peningkatan dengan persentase pada siklus I sebesar 79,55\% siklus II sebesar $82,79 \%$ dan pada siklus III sebesar $85,47 \%$. Aspek rasa senang siswa terhadap guru dan materi persentasenya pada siklus I sebesar $71,47 \%$ siklus II $76,47 \%$, dan pada siklus III sebesar 80,59\%. Aspek keterlibatan siswa dalam pembelajaran pada siklus I sebesar 75,59 \% siklus sebesar II 78,68\% dan pada siklus III sebesar $82,50 \%$. Aspek kesadaran akan adanya manfaat pada siklus I sebesar $73,97 \%$ siklus II sebesar $78,82 \%$ dan pada siklus III sebesar $85,44 \%$.
Hasil penelitian ini didukung pula dari penelitan lain yang dilakukan oleh Abdullah Husin (2009) dengan judul "EFEKTIVITAS MODEL PEMBELAJARAN QUANTUM TEACHING TERHADAP HASIL BELAJAR MATEMATIKA PESERTA DIDIK POKOK BAHASAN SEGITIGA SEMESTER II KELAS VII MTs NEGERI MARGOYOSO PATI TAHUN PELAJARAN 2008/2009". Hasil penelitian menunjukkan t-hitung= 2,811, dan dari tabel distribusi $t$ diperoleh $\mathrm{t}$-tabel $=1,66$ dengan $05.0=$ $\alpha$, dan $\mathrm{dk}=34+34-2=66$. Hal ini menunjukkan bahwa t-hitung> t-tabel, jadi H1: $\mu 1>\mu 2$ diterima. Artinya, bahwa rata-rata hasil belajar peserta didik kelas eksperimen yang diajar dengan model pembelajaran Quantum Teaching pada materi segitiga berbeda secara nyata dari rata-rata hasil belajar peserta didik kelas kontrol. Dari hasil penelitian diperoleh rata-rata kelas eksperimen $x=65.67$, dan rata-rata kelas kontrol $\mathrm{x}=58,7$. Hal tersebut nampak bahwa rata-rata hasil belajar peserta didik yang diajar dengan model pembelajaran Quantum Teaching pada materi segitiga lebih baik dari rata-rata hasil belajar peserta didik yang diajar dengan pembelajaran konvensional. Hal ini berarti bahwa model pembelajaran 
Quantum Teaching efektif untuk meningkatkan hasil belajar peserta didik pada materi segitiga.

Keefektifan model Quantum Teaching ini tidak terlepas dari ciri khas dari pembelajaran itu sendiri yaitu pembelajaran nyaman dan mengutamakan kebebasan siswa dalam berkreasi sehingga mengundang potensi munculnya kreativitas dan pengalaman siswa dalam proses menemukan sesuatu yang baik.

\section{KESIMPULAN}

Berdasarkan hasil penelitian yang telah dilakukan oleh peneliti maka kesimpulan dari hasil penelitian ini adalah:

1. Model Kooperatif tidak efektif digunakan dalam pembelajaran matematika pada materi Bangun Ruang Sisi Datar khususnya Kubus. Hal ini dapat dilihat dari jumlah siswa yang mencapai nilai KKM pada kelas kontrol lebih dari $70 \%$. Selain dari data kuantitatif tersebut, ketidakefektifan dari model Kooperatif ini juga didukung dari hasil perhitungan secara statistik (dengan SPSS 16.0) dimana nilai signifikansi sebesar 0,004 dengan taraf nyata 5\% sehingga nilai signifikansi lebih rendah daripada taraf nyata yaitu $\quad \alpha=0,05>0,004$ dan dapat disimpulkan bahwa model Kooperatif tidak efektif.

2. Model Quantum Teaching tidak efektif digunakan dalam pembelajaran matematika pada materi Bangun Ruang Sisi Datar khususnya Kubus. Hal ini dapat dilihat dari jumlah siswa yang mencapai nilai KKM pada kelas eksperimen lebih dari $70 \%$. Selain dari data kuantitatif tersebut, keefektifan dari model Quantum Teaching ini juga didukung dari hasil perhitungan secara statistik (dengan SPSS 16.0) dimana nilai signifikansi sebesar 0,020 dengan taraf nyata $5 \%$. Karena nilai signifikansi lebih rendah daripada taraf nyata yaitu $\alpha=0,05>0,020$ maka dapat disimpulkan bahwa model Quantum Teaching tidak efektif.

3. Model Quantum Teaching lebih efektif daripada model Kooperatif. Hal ini dapat dilihat dari jumlah siswa yang mencapai nilai KKM pada kelas eksperimen berjumlah 13 siswa sedangkan jumlah siswa yang mencapai nilai KKM pada kelas 
Efektivitas Pembelajaran Matematika Dengan Model Quantum Teaching (QT) Ditinjau Dari Kreativitas Belajar Siswa Kelas VIII SMP N 2 Turi

Monita Dwiyani, Niken Wahyu Utami

kontrol berjumlah 12 siswa. Selain dari data kuantitatif tersebut, kesimpulan bahwa model Quantum Teaching lebih efektif dibandingkan dengan model Kooperatif juga didukung dari hasil perhitungan secara statistik (dengan SPSS 16.0) dimana pada uji proporsi dua populasi dengan nilai signifikansi sebesar 0,869 dengan taraf nyata $5 \%$. Karena nilai signifikansi lebih besar daripada taraf nyata yaitu 0,869>0,05 sehingga dapat disimpulkan bahwa model Quantum Teaching lebih efektif daripada model Kooperatif.

\section{REFERENSI}

Budiyono. 2003. Metodologi Penelitian Pendidikan. Surakarta: Universitas Sebelas Maret Press.

-------. 2004. Statistika untuk Penelitian. Surakarta: Universitas Sebelas Maret Press.

Hamruni. 2011. Strategi Pembelajaran. Yogyakarta: Insan Madani.

Purwanto. 2011. Statistika untuk Penelitian. Yogyakarta: Pustaka Pelajar.

Sumaryanta. 2009. Perencanaan Pembelajaran Matematika. Yogyakarta: UPY.

Tim penulisan buku psikologi pendidikan. 1991. Psikologi Pendidikan. Yogyakarta: UPP IKIP Yogyakarta.

Tomo Djudin. 2013. Statistika Parametrik. Yogyakarta: Tiara Wacana. 